\title{
How do Master Teachers plan to renew early childhood education in Hungary? - The five-year plans of the Master Programmes and their implementations
}

\author{
IVETT JUDIT KOVÁCS ${ }^{1^{*}}$ (@), JUDIT SZIVÁK ${ }^{1}$ (]) and \\ ERZSÉBET CZACHESZ
}

\author{
${ }^{1}$ Eötvös Loránd University, Institute of Education, Budapest, Hungary \\ ${ }^{2}$ Eötvös Loránd University, Institute of Intercultural Psychology and Education, Budapest, Hungary
}

\section{RESEARCH PAPER}

Received: October 28, 2020 • Accepted: November 2, 2020

Published online: April 10, 2021

(C) 2021 The Author(s)

\begin{abstract}
In Hungary, the teacher qualification and promotion system was extended with the missing Master teacher grade in 2016. The analysis of the five-year plans of the Master teacher candidates provides an opportunity to get an overview of the vision of experienced and highly qualified teachers about the current situation and the potentials of the educational sector. The research explores the Master programmes of 95 Master teacher candidates from the early years sector to understand what issues they identify in their everyday work, which motivates them for professional learning and for setting innovative goals. The qualitative research uses document analysis to explore the programmes that is followed by semi-structured interviews. The Master kindergarten teachers consider teacher fluctuation and the changes in the legislation the main issues that induce extra tasks to deal with. They also plan to enrich their practice with innovative methods. Collaborative methods for professional learning and planning are frequently mentioned in the programmes, but the terrain of knowledge sharing is mainly their community of practice. Even though opposition is visible in the teachers' attitude against the qualification network, the majority of the Master teachers claim to consider their master programme as an enhancement of their professional work.
\end{abstract}

\footnotetext{
*Corresponding author. E-mail: kovacs.ivett@ppk.elte.hu
} 


\section{KEYWORDS}

teacher qualification system, professional learning, kindergarten teacher's professional development, early childhood education, collaborative learning of teachers, master teachers

\section{INTRODUCTION}

The research examines the plans and the implementation of the Master Programmes of those teachers who have reached the highest level of proficiency and completed the master's degree in Hungarian teacher training. Teachers who enrol to complete the degree compile a portfolio of professional work for the forthcoming five years, with the goal of improving and revitalising their institutions and professional communities, in addition to their own practices. International researches and evaluations of the programmes have unanimously concluded that receiving a high-level institutionalised education during early childhood has positive impacts on children's well-being, learning abilities and development, and might create a strong basis for lifelong learning (OECD, 2017). The teachers' continuous professional development, which is the learning process that brings along changes in their teaching practices, and therefore in the development of the children's outcomes (Darling-Hammond \& Richardson, 2009), has key importance regarding the level of professional work. Although several forms of learning activities embedded in the teachers' work have been identified by empirical studies (Kwakman, 2003; Hoekstra, Beijaard, Brekelmans, \& Korthagen, 2007; Kyndt, Gijbels, Groseman, \& Donche, 2016; Schei \& Nerbo, 2015), their formal instalment into the elements of the teachers' progress is still problematic. The research examines the effect of the implementation of the Master programmes on teachers' everyday work and professional development.

\section{LITERATURE REVIEW}

\section{The master's degree within the teachers' training system}

The teacher qualification and promotion system (TÁMOP 3.1.5/12) was created as a strategic project within the framework of the Social Renewal Operational Programme's Comprehensive Quality Development in Public Education, with the aim of improving the quality, effectiveness and efficiency of education in Hungary. The two main goals of the project were the elaboration of the accountability system and the support of the institutions' developments based on organised learning. The new system came into effect as of September 1st, 2013.

Three different types of the highest Master Teacher degree were introduced (Government Decree 326/2013. (VIII.30.)): the expert Master Teacher, who takes part in pedagogical-professional monitoring; the consultant Master Teacher; and the Master teacher, who implements the Master Programme. The latter also chooses a focus of activity in their programmes which can be: an innovator, a mentor, or a head of an institution, however, the appearance of all the activities is compulsory in all programmes. While the first two types of degrees mentioned remain valid until the end of the teachers' career, the Master Programme is required to be renewed every five years - and the teachers who do not renew their programmes are 
downgraded to their former grade and former salary category. The attainment of the master's degree and the procedure of authorisation of its renewal are subject to fees.

The development of the qualification tools and procedures connected to the Master Teacher degree and Researcher Teacher degree happened within the framework of a pilot programme titled Completion, Testing and Revision of the Teacher Qualification System (TÁMOP-3.1.5/12-2012-0001) in 2014-2015. The requirement for acceptance was to have at least 14 years of pedagogical professional experience and qualities built on innovation and research. More than 5,000 teachers completed the application that was sent out to enable admittance onto the programme. Based on an evaluation system, 1,200 of them were selected, who in 2015 within the framework of the project developed and uploaded their Master Programmes and Research Programmes. The teachers who participated in the pilot project worked in adherence to a draft of guidelines and based on the experiences, the final guidelines for the qualification procedure for the Master Teacher and the Researcher Teacher grades were published in 2016 .

During the interim phase of its introduction (2013-2018), the related laws and decrees underwent several modifications. "Ever since its introduction on September 1st, 2012, the Public Education Law was modified 43 times by the government. The corrections concerned the teachers' promotional system in seven cases." (Lunczer, 2018, p. 15).

One of the three main objectives in developing the Master Teacher degree (alongside the improvement in the efficiency of the public education system and the increase in the prestige of the teaching profession) was to develop a system of continuous professional development (Oktatási Hivatal, 2018, p. 8). The Master Teachers' “professional activities can be defined as alongside the following four dimensions: the exploring-analysing, the developing-innovating, the knowledge-sharing and helping activities and the activities of continuous professional development" (Oktatási Hivatal, 2018, p. 11). Owing to the focus that was directed towards the four dimensions, a great amount of emphasis was placed on the "interpersonal and organizational knowledge" during the implementation of the Master Programmes (NOIR+, Kovács, 2015, p. 334), in harmony with the NOIR + strategy that provided its theoretical background.

\section{The most important characteristics of kindergarten teachers' professional development}

The most important models of teachers' continuous professional development (Guskey, 2002; Desimone, 2009; Clarke \& Hollingsworth, 2002; Evans, 2014; Opfer \& Pedder, 2011) agree that professional learning cannot be restricted exclusively to participation in compulsory and intentional activities. Instead, it means that a learning activity is located at any point of the formal-informal continuum and it "initiates" momentary or permanent change in the various teachers' “outcomes” (practice, knowledge, attitude, etc.) (Rapos, Bükki, Gazdag, Nagy, \& Tókos, 2020, p. 30).

By the concept of learning, different forms of knowledge acquisition are understood in this study, including tacit knowledge - and the process is described by the metaphors of building or constructing. The new knowledge manifested during the everyday practice of teachers - especially if it is accompanied by reflection and discussion with colleagues - is their most important source of professional knowledge (Kovács, 2015).

When teachers' professional learning is explored, along with the individual factors (cognitive, motivational and affective aspects), the identity (Kelchtermans, 2005; Evans, 2014; Korthagen, 
2017), the organisational aspects (Engeström, 2001; Fuller \& Unwin, 2004; Goe et al., 2008; Paniague \& Sánchez-Martí, 2018; Qiu, 2018) and the supportive, controlling and supervising elements of the system must also be taken into consideration (Anderson-Levitt, 2003; Caena, 2011).

Participation in formal and informal learning activities is strongly influenced by the professional attitude, the task factors related to stress, the difficulty of the challenge (Kwakman, 2003), and the restrictive and expansive organisational elements of the working environment (Fuller \& Unwin, 2004). In the shaping of the latter, leadership and leading strategies play a definitive role and in relation to these the assessment and the feedback of the professional work. These all are influenced by the system-level factors, like the distribution of the financial resources provided by the government, the elements and the vision of the teacher qualification and promotion system, the legal regulation or the formal training opportunities (Lénárd, Kovács, Tóth-Pjeczka, \& Urbán, 2020).

Empirical research in the kindergarten context identified ten different activities that contribute to professional development. Four of the ten are individual learning activities (practicing, experimenting, reflection, and reading literature), but the other six are manifested through interaction with others (discussion, asking for professional advice, observation, mentoring, critical comments, training) (Schei \& Nerbo, 2015). In Jensen and Iannone's research (2018) critical reflection, communities of practice, and networking were identified as crucial aspects of kindergarten teachers' professional development in terms of innovation. The initially "outside-in" process of professional learning ideally turns into an "inside-out" process with time (Sheridan, Edwards, Marvin, \& Knoche, 2009). This means, that learning initially led by outsider lecturers and coaches is gradually becoming a collective responsibility via reflective practice and collaboration. That is of great importance, since the formal, out of setting trainings cannot guarantee the ascent in the quality of the service: various aspects can inhibit the application of the new approaches or knowledge in everyday practice (Brown \& Inglis, 2013). Kindergarten teachers find it more effective to engage in informal learning activities compared to formal trainings (Múñez, Bautista, Khiu, Keh, \& Bull, 2017). The literature identifies three factors as the most important conditions of intrinsic professional development: supportive leadership, motivating professional challenges, and collaborative professional communities (Wagner \& French, 2010). These conclusions show that the ideal learning situation happens when the kindergarten teaching staff or smaller professional groups work as communities of practice - working cooperatively on shared, relevant problems, with commitment towards the tasks, along with shared professional views and vision - with the aim to renew their practice (Wenger, 2002). This is called by Engeström $(1987,2001)$ expansive learning, when during collaborative problem solving and reflection, collective learning is manifested and new knowledge is created. Empirical research argues that collaboration among kindergarten teachers also raises their level of selfefficacy (Guo, Justice, Sawyer, \& Tompkins, 2011; Epstein \& Willhite, 2015; Múñez et al., 2017). The most effective practice-embedded collective learning is realised in knowledge-intensive organisations (OECD, 2000), where the organisational environment builds strongly on the individual knowledge of the teachers (Hargreaves, 1999). The ideal method of extending professional knowledge within the organisation is to operate as a learning organisation (Senge, 1998; Kools \& Stoll, 2016) where even new knowledge is created by double-loop learning (Argyris \& Schön, 1978). 
Although in the international field, there are empirical research projects on teachers' professional development also within the kindergarten context (etc. Jensen, Jensen, \& Rasmussen, 2015; Múñez et al., 2017; Vujičić \& Tambolaš, 2017), in Hungary, this area is still uncovered. The view that the kindergarten context plays a minor role compared to the other levels of public education in Hungary is not solely restricted to scientific research. Generally, in professional and societal discourse, kindergarten teachers do not receive the deserved recognition for their work which is reflected in their own perception regarding their profession (Szarka, 2004).

\section{RESEARCH}

\section{Research questions}

1. What were the most significant considerations during the planning and writing phase?

2. To what extent did the teachers manage to achieve the goals they had formulated in their Master Programmes?

3. Did professional development materialise during the planning, writing, or implementation stages of the Master Programme?

4. Are the teachers planning to renew the program?

5. How do teachers reflect on their new roles, tasks, and achievements since becoming a Master Teacher?

\section{Research methods and sample}

The empirical study used two different research methods in three steps (see Table 1). As the continuation and expansion of firstly the Master Teachers Research of ELTE PPK (MEK Mesterpedagógus kutatás, see Szivák \& Pesti, 2020), and secondly the exploration of the Master Programmes of the kindergarten subsample (95 people) within the research's database (Kovács, Szivák, \& Czachesz, 2020), a qualitative study was conducted to explore the implementation of the programmes. The empirical data collection through a field-work qualitative study was based on the results of the qualitative analysis of the documents titled General Plan and Plan Part that entailed the study of 1,847 pages of text altogether, with the focus of the research questions.

Table 1. Research methods and sample

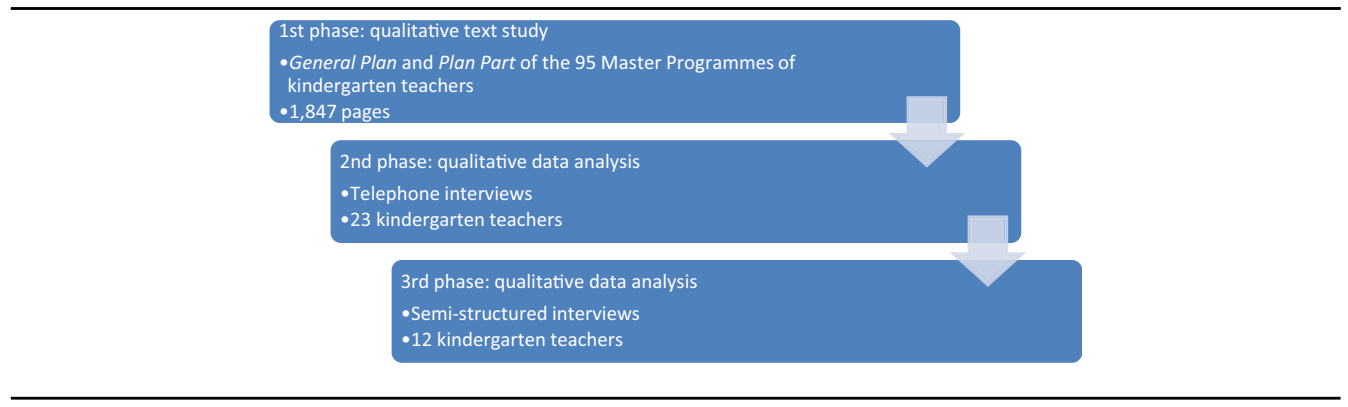


The interviewees were chosen by the convenience sampling method from different parts of Hungary. We got hold of 23 Master Teachers on the phone, qualified by pilot testing, who provided us with basic information regarding the implementation and the renewal of their Master Programmes. Out of them, 12 consented to do the semi-structured, in-person interviews. The conversations were based on an interview scheme, and they lasted between 60 and 90 minutes each. The data was analysed using a rigorous thematic approach based on the research questions (Braun \& Clarke, 2006).

\section{RESULTS}

For the introduction of the results, the data collected from the different sources combined was interpreted. The chapters introducing the planning and the writing phase, and the professional development are based on the data collected during the interviews and the data gained from the textual analyses of the plans. The chapters analysing the implementation, the renewal, and the reflection on the Master teacher role are based on the data collected from the telephone and personal interviews.

\section{What were the most significant considerations during the planning and writing phase?}

The attitude. All the interviewed kindergarten teachers considered getting on the pilot scheme as an acknowledgement of their professional work. They regarded writing the programme as a professional challenge. Being participants of a pilot process, they had to face challenges caused by lacking clear guidelines and criteria, but they could get answers through letters from the organizers and they were also helping each other on online platforms that were created specifically for them. Those teachers, who had no experience in writing professional documents or had no supportive professional community, had major difficulties compiling the documents.

"The evaluation based on the four dimensions was somewhat new for me. We didn't have guidelines on that. I searched a lot on all aspects of the topic because if someone writes a portfolio or decides to undertake a bigger project, she checks on all the little details. So I refreshed everything beginning from the pedagogical methods to make sure to have it right..."

However, most of the interviewed teachers have had experience in writing documents of a type - as a consequence of participating in many trainings before or even working actively as a trainer.

"We didn't have any other standing-ground apart from the pilot guide, but I was not shocked by that. I know some colleagues had a very hard time and found it very demanding to work without precise guidelines, but I didn't mind - I even enjoyed it, that I was not told what to do...”

It was also a great help when there were more colleagues within one institution or professional community writing the pilot and could cooperate during the process. The online Master groups created by the pilot organizers included teachers from all educational levels, therefore the members provided mainly technical and administrative support for each other.

At the planning phase, besides the task of organizing the professional ideas into a time frame and a system, in most cases, new elements were added to the everyday work. There was a slight 
discrepancy over the subject if the programme is supposed to have new elements in it or can simply continue the high-quality professional work.

"It was a long process to decide how to build up the programme - I am convinced, that this is the only way to do it. I believe, that presenting the work someone has completed before, is not enough, a master programme cannot simply be built on that - it has to include an innovation! Otherwise, I cannot see the point of a programme, if we don't have achievement at the end..."

Some of the mentor profile programmes decided not to introduce new elements claiming that merely carrying on with their outstanding professional work they merit the Master teacher degree.

"I am planning to continue the activities I have already started and have been doing for decades - of high quality and serving as a role model with continuous professional development and renewal supported by my institution and leaders."

One participant mentioned in an interview how already the process of planning and writing was a time full of joint professional development, during which the interviewee, as the leader together with the teacher community, decided about what new methodology elements they are going to experiment within the next five years.

"It was a trial phase, it took us weeks, even months, to set up the professional-methodological part together, then we assigned to it the different knowledge, then we put them into the groups and observed how they worked. We did it for weeks to see what needed to be cut out and what could be left in it..."

Choosing the profile and the focus. All the teachers considered the institutional benefits of the programme when they chose the subject(s). The interviews unequivocally show that kindergarten teachers who enrol in the master's degree programme take on and carry out tasks that exceed far beyond everyday routines. They search for new challenges while seeking new solutions for problems and expectations that occur in everyday life.

"I could have chosen the mentor profile because I was mentoring and teaching at the university, so it would have been easy for me. . . But it was more exciting for me, that I haven't seen anyone choosing the leader profile... We didn't know where this whole thing will end up... As I see, that if you are a head of an institution, you have to be adept at everything. Then you are a mentor, and also a researcher, because how can you write a yearly report without gathering data?"

Based on the Master Programmes' situation assessments and activity plans, the outlined tasks of the Master Teacher candidates can be categorised according to three main groups.

1. Introduction of innovative methods in order to improve the quality of professional work.

In some cases, Master teachers decided to develop innovations due to acknowledging that a tool is missing from their practice. However, in the majority of the cases, teachers transferred the innovations they had already tried and tested in their groups into their Master Programmes for further development or dissemination. Others planned to join a network of institutions (typically to obtain the Green Kindergarten title and the Talent Point accreditation). The most frequent topics include talent development and inclusion for the disadvantaged, and also music education, folk dance, ICT, or the novelty use of tales and puppets. The strengthening of the cooperation with parents also appears in several programmes, and it is frequently linked to the 
integration of the disadvantaged or Roma children. The majority of the programmes aspire to the development of a method often as the result of the changes regarding the specific features of the institution or due to the changes in legislation. Such change, for example, is the increasing emphasis on environmental awareness and sustainability in education, and the intensified emphasis on learning about folk traditions. The development of the institution's internal professional and documentary work also appears as an innovation, for example the introduction of project-based group diaries or the task of the kindergarten's marketing. The methodological elaboration of utilising such pedagogical methods that have been proven within school environments and applying them in a kindergarten context - for example, cooperative techniques or museum pedagogy -, also appear among the innovations.

2. Providing professional development and qualification of the teacher community.

In the situational analysis of the programmes, teachers mentioned the tasks relating to the maintenance of staffing as one of the most serious problems. Due to the large number of colleagues who were due to retire within a couple of years, Master Teacher candidates anticipated a lack of teachers, parallel to the continuous tutoring of the new entrants into the institutions. The professional and socialising support given to the institution's new entrants weighs on the colleagues, which also occur alongside the multiple tasks connected to their evaluations.

„Within 3 years $85 \%$ of the colleagues will be replaced - and mainly entrants will join us. There will be many entrants teacher that is an extra challenge."

In connection to avoiding and preventing burnout, the question of mental health also emerged as an important element of some programmes - primarily due to the constantly rising average age of the teachers, the requirements of the teacher qualification and promotion system, the growth in administrative duties, as well as the increasing workloads resulting from the shortage of educators.

3. The efficient operation of the institutions in the context of the changing legal background and reorganisations.

The leader programmes characteristically try to keep pace with the rapid changes of legal regulations at the highest possible level and with the utmost accuracy, which, based on the Master Programmes and interviews, is a strenuous and stressful task. The preparations for the qualification procedures and the execution of school inspection supervision mean continuous tasks at many institutions. The elaboration and operation of an internal evaluation system alongside the changing legislations are also connected to it.

The leader programmes also target inner structural development, which often means the completion of new tasks that arise as the result of reorganisation at the time when the institutions are expanded with member kindergartens and groups. The fusion of kindergartens requires the rewriting of the pedagogical programme, which entails the unification of group diaries, the reorganisation of work groups and the task of community building. The plan for the formation of a learning society appears explicitly in three programmes as the best way of organisational and professional development. 


\section{To what extent did the teachers manage to achieve the goals they had formulated in their Master Programmes?}

In the second phase of the research, 23 Master Teachers were contacted on the phone and by mail, among whom 19 educators gave information regarding the implementation and renewal of their Master Programmes. Eleven teachers managed to implement their programmes fully, two partially, and six could not execute them: five of them retired before the programme's planned five-year term ended, and in the case of one educator, the new head of her institution did not support the implementation, and thus, she now works as an expert.

Implementation was made difficult or was obstructed by several factors:

- The significance of the leader's support was mentioned in every interview - usually with a positive connotation. The lack of support from the management, however, undoubtedly hinders the educators' innovative initiations. One educator, for example, was compelled to switch to become an expert, because her endeavours were not supported by the new head of the kindergarten.

- Lack of time appeared as one of the greatest difficulties of implementation in the interview responses. In many cases, the planned activities appeared to be exaggerated, and the completion of everyday chores left little room for further commitments.

- The frequent changes in the legislative environment and legal provisions also resulted in inconveniences, which in many cases, meant the re-completion or re-planning of tasks.

"I wrote a plan for developing an inner evaluation system. The official guidelines for the inner evaluation system of kindergartens were given out later, in December of 2015, but it has nothing to do with all the information that was spread at professional forums and lectures before. So I had to start all the planning again."

- Experiences show that the nature and methods of the controlling mechanisms greatly influence the planning of the professional activities and learning progressions, as the accounts given about the implementation of the programmes should be supported by documents.

In the renewal, "I left out the movement therapy. Not because I don't do it, but it's hard to document. One cannot write a report on it, it is full of personal details that cannot be published... I replaced it with something easier to document."

- In several cases, the implementation was made difficult due to financing problems. This was typically in such instances when the agreement included covering the expenses partly from external sources. In one case, for example, during the reconstruction of a kindergarten, there were no funds left for the planned outdoor traffic education course, in another case, the local council withdrew from financing a previously agreed training.

- Even though all the teachers planned to disseminate their achievements to a wider professional community, knowledge sharing did not result in publications on a country level. The less frequent way of sharing knowledge is written publication - several teachers emphasised in their interviews that they were happy to share their knowledge with the wider professional community at conferences or workshops, however, they do not wish to spend time or energy on writing professional texts. 


\section{Did professional development materialise during the planning, writing, or implementation stages of the Master Programme?}

All the interviewees unequivocally reported significant professional learning as a result of the implementation of the programme. Two main types of learning were mentioned. Firstly, they gave an account of their practices becoming more considered and more intentional, and secondly, they described the formation or the strengthening of their professional practice community.

\footnotetext{
"It is for sure that writing the programme gave a focus to my ideas. Obviously, I read a lot more on the topic; I participated in conferences, organized and led workshops; I initiated partnerships with schools. Surely, it inspired me, but I believe that without it, my life would have followed the same direction - maybe in a less focused, less scheduled, less conscious way."
}

The collaboration of teams, smaller professional groups, or the whole teaching staff was greatly emphasised in all programmes and interviews. The collective consideration of personal ideas appeared several times - or even more, as the outcome of certain elements of the programmes, collaboration becomes an integral part of the kindergarten's everyday life. In many cases, the practice of organising and implementing collective learning within the organisation became part of everyday practice based on the Master Programmes.

"To learn the new child assessment method, I managed to bring the training here from Budapest, and we all participated. But love and retirement came, and again we had new colleagues without the knowledge - so we established a team to mentor the new ones. Because the method did not cover all the necessary areas, we were experimenting a lot and formed a team to elaborate the missing parts. When this was already accomplished, it became clear that we also needed a team for measurement and evaluation - to elaborate a system to record and analyze the data..."

\section{Are the teachers planning to renew the program?}

Out of the 23 Master Teachers, only six plan to renew the Master Programme; three of them work as a different-profile Master (expert, consultant) now; eight have already retired or plan to retire after the five-year period, three do not wish to renew it, and we received no information regarding their plans for renewal from three of them (see Table 2).

According to the data collected through the interviews, the teachers who had the chance to apply for the Master degree are close to the end of their career path and have nearly forty years of professional work behind them. Some of them find the task of renewal too overwhelming:

Table 2. Plans of the interviewed teachers for renewing the programme

\begin{tabular}{lcc}
\hline Will renew it & $26 \%$ & \\
\hline Will not renew it & $60 \%$ & Altogether \\
& $13 \%$ & Works in a different Master profile \\
& $34 \%$ & Retired/will retire \\
& $13 \%$ & No intention to renew it \\
\hline
\end{tabular}

No information

$13 \%$ 
writing the portfolio, going through the qualification procedure and the requirements of the implementation of the programme mean excessive extra work in the everyday practice.

"I do not apply for renewal. I take a little break. I know I will be downgraded to Teacher II. . . But I feel tired now and I want to rest. I saw my colleague do it - the writing part and the qualification exam, like a Ph.D... . It does not mean that I might not apply again some years later. I accepted that the extra work and the renewal are part of this degree - so I have the opportunity, but I have to work for it. .."

Others have new plans in mind since being a trainer, and fulfilling the duties of a head of an institution and working with the group as a teacher simultaneously is too overwhelming even with outstanding commitment and enthusiasm.

"I will not renew it because in 2020, I will finish my forty years of employment, and I have to terminate a period. I decided not to keep doing the everyday treadwheel anymore because it is too overwhelming, and now I can pass the relay baton to the next leader the same way the runners do: that the next racer is also full of go and can keep running. I have got requests from national organizations, so I will keep working. .."

\section{How do teachers reflect on their new roles, tasks, and achievements since becoming a Master Teacher?}

Master teachers serve as role models in their institution, proving that the teacher qualification system does not set irrational expectations: it is possible to compile a portfolio and go through the qualification procedure with success. They frequently mentioned in the interviews that many of their colleagues shun evaluation, in fact, the whole teacher qualification and promotion system. They find it humiliating that they have to prove the success of their everyday work competence by uploading documents, and as a result, they often abandon their profession instead.

"Currently we have two or three colleagues who might simply leave when it will be compulsory for them to go through the qualification procedure... They cannot retire yet, being too young for that, so they'll rather leave the profession. They are good kindergarten teachers, but they simply do not feel that they can make it..."

A Master Teacher has a significant role in their institution in supervising their colleagues to step ahead in the teacher promotion system. They mentor them in acquiring the concept of the four dimensions model, help them in collecting and writing the documents and prepare them for the exam. They serve as role models by demonstrating a commitment to continuous professional development and an innovative approach. Still, they feel that the increased burden brought about by the evaluation procedures and the monitoring of the school inspection weigh on them, as do all the tasks that concern the whole community. Furthermore, the large workload that goes along with the low wages further aggravates the already notable shortage of educators.

In the interviews, teachers reported on the tension caused by the differences in salaries. Their colleagues expect the Master Teachers to complete certain extra tasks for the higher pay. The different requirements, entitlements, and allowances of the three types of master's degrees also cause tension among the teachers. The teachers also mentioned the controversial idea of "what makes" a "Master teacher"? 
"I should not get the degree for creating a traffic education course in the garden... I should merit the degree for the high quality of work I do with kids. I can write documents and have meaningful discussions with adults about the profession, but if I work as a kindergarten teacher I should get the degree for doing my job with the kids at a Master level...."

Several interviewees mentioned the low social recognition of the kindergarten teacher profession. The expression "only kindergarten teacher" was used and even the questionnaire of the pilot programme enhanced their feeling of neglect - containing only two out of 100 questions related to kindergartens and kindergarten teachers.

All the Master Teachers who accepted to do the interview were happy to talk about the work they carried out in the framework of their Master Programme - their words reflected pride and the joy of professional work well done.

\begin{abstract}
"The first thing was that the people who judged or evaluated my work found my plan worthy of completion. The next step was that it was inspiring - a lot of people are in the burnout phase during this descending stage of their career - and then other people give you a paper that proves that it's indeed a very important job... Then it was good for digging deeper: how can we do it better or more... Obviously, for all this I have to train myself, and not for the paper, but for me to stand my ground in these novel tasks. Anyone who writes a portfolio once will be given the attitude that I excelled in something!"
\end{abstract}

\title{
DISCUSSION
}

1. What were the most significant considerations during the planning and writing phase?

Compiling the portfolio without clear and detailed guidelines was a challenge but also a professional adventure for most of the Master Teachers because the task of planning for five years helped them to structure their goals and ideas. The teachers felt that the Master Programme should bring novelties, something more than everyday practices, and at the same time, they also felt it unjust that the fulfilment of everyday practices on a high level, based on several decades of experience, does not constitute Master-level professional work by itself. Teachers with a mentor profile generally planned to continue their everyday practice focussing on the extra duties of mentoring the interns and students on practice; the innovators brought a new element into their professional work or planned to disseminate their good practices; the leaders mainly planned to focus on rewriting the compulsory documents and setting up an inner evaluation system according to the new legislations.

2. To what extent did the teachers manage to achieve the goals they had formulated in their Master Programmes?

A significant proportion of the pilot's participants retired before the end of the five years, thus, they did not implement their programmes. The interviewed teachers, however, aspired to develop their own practices, as well as those of their organisation, which in most cases was realised by active professional collaboration resulted in informal professional learning supported by the organization (Engeström, 2001; Fuller \& Unwin, 2004; Goe et al., 2008; Paniague \& 
Sánchez-Martí, 2018; Qiu, 2018). The difficulty of implementation showed diversions depending on the leader's support which means that the Master Teachers with leading positions could have a stronger influence on the institution's operation. The implementation was obstructed by several factors, like the lack of time, financing problems, the availability of external partners, or changes in the legislative environment. The measure of support from the side of their leaders strongly influenced the work of those Master Teachers who do not work in leading positions, which in unfortunate cases, made the implementation of the Master Programme impossible. Master Teachers working in smaller towns, basically in isolation, fight a lonely fight, which in the case of not being successful, can cause burnout.

3. Did professional development materialise during the planning, writing, or implementation stages of the Master Programme?

Based on the interviews, implementing the Master Programmes brought along a high degree of professional development in all cases. Writing the programmes also transpired as an individual learning process (Shei \& Nerbo, 2015): primarily for systemising the ideas, elaborating the plans, and putting them into a time frame. In the implementation, teachers reported professional development as the result of studying the literature, testing innovations, knowledge sharing and collaboration (Jensen \& Iannone, 2018).

From the planning and the implementation of the Master Programmes, it is apparent that alongside the formal trainings, the informal learning progressions constitute an integral part of the professional development of the Master Teachers, which coincides with the strategy that lies behind the degree's elaboration (Szivák, Rónay, Saád, \& Fazekas, 2019). The progression from outside-in to inside-out process of learning (Sheridan et al., 2009) could also be detected in several cases as the by-product of the implementation of the program. In the interviews, Master Teachers often talk about such internal operations where expansive learning materialised (Engeström, 1987, 2001), or even more, about the operation of a knowledge-intensive learning organisation (Senge, 1998; Kools \& Stoll, 2016; OECD, 2000) - that was frequently identified as something that was brought along as the by-product of the Master Programme.

4. Are the teachers planning to renew the program?

No more than $26 \%$ of the interviewees planned to renew the programme. The reasons behind this low number partly originate in the ageing kindergarten teacher community and the strict regulation that enables teachers not long before their retirement to apply for the degree. The results showed that all three factors: personal, organizational, and system-level elements played an important role in the decision regarding renewal (Lénárd et al., 2020). According to the research results, the programme implementer type of the Master teacher degree - especially compared to the other types - seems to make such heavy demands on the teachers that are felt not to be compensated by the increased salary. The mandatory renewal every five years, and the shorter paid time off work makes programme writing more unfavourable even though it has substantially more benefits for the organization and the Master teacher has less reduction in working hours.

5. How do teachers reflect on their new roles, tasks, and achievements since becoming a Master Teacher? 
The majority of the Master Teachers believe that they convey value with their work to their immediate and wider environment. As a role model, they endeavour to motivate their colleagues towards progression, and they talk about their own Master Programme and their implementation positively.

Being familiar with the results of the research and the literature dealing with the concept and nature of professional knowledge, it can be stated that the implementation of the Master Programmes clearly helps tacit knowledge to turn into explicit professional knowledge. Therefore, it takes a huge step towards the target formulated during the elaboration of the Master Programme degree, which aims to strengthen the efficiency, success, and innovation potential of the teachers and the schools with the tool of successful knowledge management (Kovács, 2015).

Based on the interviews, the growth of the professional self-efficacy and the strengthening of the collaborative work forms can be denoted as the two most important by-products of the implementation of the Master Programmes.

\footnotetext{
"There was a little team around me, that I could always rely on. They gave me reinforcement or advice: they volunteered to be part of the working community to provide a professional base for my master programme..."
}

The team of kindergarten teachers who work together on the rethinking of the pedagogical programmes and elaborating the methods of differentiation can be understood as communities of practice or as professional learning communities who search for the solution together for a problem that is relevant to their work, they share their knowledge and experiment together (Engeström, 1987, 2001; Wenger, 2002; Wagner \& French, 2010).

They have the huge professional knowledge to share, but most of them do not feel the strength and impetus to find the suitable channels for it - not having enough well-working networks and practice for sharing knowledge on a country level in the sector of the early years education. Master kindergarten teachers tend not to publish their work in professional papers. Therefore, the knowledge sharing mostly happens within the institutions, and sometimes within the larger community, but kindergarten teachers work in effective cooperation within the organisations that support professional development in the innovations and the improvement of the organisation.

\section{CONCLUSION}

The results of the research paint a complex picture of the Master Teachers' work and the professional experiences concerning those who qualified in the pilot programme. Even though some problematic features of the practical realisation of the teacher qualification and promotion system were revealed, the writing and the implementation of the Master Programme proved to be an inspiring professional challenge, in the respect of renewing the practice, professional learning, and organisational development. It is well marked from the results that there is an essential need to establish a well-working The Master Teacher network that was envisaged as one of the pillars of knowledge management in the NOIR + strategy. This would ensure that the external introduction and utilisation of the new knowledge and innovations accomplished through the Master programmes do not remain accidental. 
This inquiry can give a significant contribution to uplift the national research of the kindergarten profession and institutionalised early childhood education, and consequently, connect it to the international discourse. However, further exploration is needed for the inspection of the experiences of those Master Teachers who qualified after 2016, which would be further enriched by learning the views and experiences of those kindergarten teachers who work on the other grades of the model.

“Supported by the ÚNKP-19-3 New National Excellence Program of the Ministry for Inno-

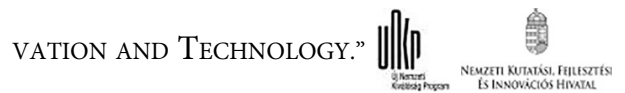

\section{ABOUT THE AUTHORS}

Ivett Judit Kovács graduated from ELTE with a degree in Hungarian Literature and Grammatics and Literary Translation. She received her doctorate at ELTE, Doctoral School of Education, and she is a senior lecturer at ELTE PPK, Faculty of Education. She works as a university lecturer at Apor Vilmos Catholic College. She has great experience in the field of early childhood education as a result of working for many years as a kindergarten teacher and also as an educational coordinator. Her research interests include international and bilingual early years education, intercultural teacher communities, professional learning, and organizational culture of educational institutions.

Judit Szivák is a habilitated associate professor at the Faculty of Education and Psychology, ELTE. She is also the head of the Research Group for Organization, Teacher and Teacher Education. She is associated with the foundation of the theoretical and research foundation of the reflective paradigm, and the development of a reflective teacher training model. Member of the Doctoral School of Education, and head of the Subject Pedagogy Program, also a lecturer and supervisor of doctoral courses. As a professional leader and expert, she is the manager of many innovations and tenders mainly in the field of teacher development and the development of teacher training.

Erzsébet Czachesz is a Professor Emeritus at the Institute of Intercultural Psychology and Education, Eötvös Lorand University, Budapest, Hungary. Her research interests and publications cover the fields of beginning reading instruction, reading comprehension, linguistic and cultural diversity, bilingual and intercultural education.

\section{REFERENCES}

Anderson-Levitt, K. M. (2003). A world culture of schooling? In Local meanings, global schooling (pp. 126). New York: Palgrave Macmilla.

Argyris, C., \& Schön, D. A. (1978). Organizational learning: A theory of action perspective. Reading, MA: Addison Wesley.

Braun, V., \& Clarke, V. (2006): Using thematic analysis in psychology. Qualitative Research in Psychology, 3(2), 77-101. https://doi.org/10.1191/1478088706qp063oa. 
Brown, A., \& Inglis, S. (2013). So what happens after the event? Exploring the realisation of professional development with early childhood educators. Australasian Journal of Early Childhood, 38(1), 11-15. https://doi.org/10.1177/183693911303800103.

Caena, F. (2011). Literature review Quality in Teachers' continuing professional development. European Commission.

Clarke, D., \& Hollingsworth, H. (2002). Elaborating a model of teacher professional growth. Teaching and Teacher Education, 18(8), 947-967. https://doi.org/10.1016/s0742-051x(02)00053-7.

Darling-Hammond, L., \& Richardson, N. (2009). Teacher learning: What matters? Educational Leadership, (2), 46-53.

Desimone, L. M. (2009). Improving impact studies of teachers' professional development: Toward better conceptualizations and measures. Educational Researcher, 38(3), 181-199. https://doi.org/10.3102/ 0013189x08331140.

Engeström, Y. (1987). Learning by expanding: An activity-theoretical approach to developmental research. Helsinki, Orienta-Konsultit.

Engeström, Y. (2001). Expansive Learning at Work: Toward an activity theoretical reconceptualization, Journal of Education and Work, 14(1), 133-156. https://doi.org/10.1080/13639080020028747.

Epstein, A., \& Willhite, G.L. (2015). Teacher efficacy in an early childhood professional development school. International Electronic Journal of Elementary Education, 7(2), 189-198.

Evans, L. (2014). Leadership for professional development and learning: enhancing our understanding of how teachers develop. Cambridge Journal of Education, 44(2), 179-198. https://doi.org/10.1080/ 0305764x.2013.860083.

Fuller, A. \& Unwin, L. (2004). Expansive learning environments: Integrating organizational and personal development. In H. Rainbird, A. Fuller, \& A. Munro (Eds.), Workplace learning in context (pp. 126144). London: Routledge.

Goe, L., Bell, C., Little, O., Van der Ploeg, A., Holcombe, A., Springer, M., et al. (2008). Approaches to evaluating teacher effectiveness. A Research Synthesis. National Comprehensive Center for Teacher Quality.

Government Decree 326/2013. (VIII.30.))/326/2013. (VIII. 30.) Korm. rendelet A pedagógusok elómeneteli rendszeréröl és a közalkalmazottak jogállásáról szóló 1992. évi XXXIII. törvény köznevelési intézményekben történö végrehajtásáról/. Magyar Közlöny 2013/143. szám.

Guo, Y., Justice, L. M., Sawyer, B., \& Tompkins, V. (2011). Exploring factors related to preschool teachers' self-efficacy. Teaching and Teacher Education, 27(5), 961-968. https://doi.org/10.1016/j.tate.2011.03.008.

Guskey, T. R. (2002). Professional development and teacher change. Teachers and Teacher Teaching, 8(3), 381-391. https://doi.org/10.1080/135406002100000512.

Hargreaves, D. (1999). The knowledge-creating school. British Journal of Educational Studies, 47(2), 122 144. https://doi.org/10.1111/1467-8527.00107.

Hoekstra, A., Beijaard, D., Brekelmans, M., \& Korthagen, F. (2007). Experienced teachers' informal learning in the workplace. Teachers and Teaching, Theory and Practice, 13(2), 191-208. https://doi.org/10.1080/ 13540600601152546.

Jensen, B., \& Iannone, R. L. (2018). Innovative approaches to continuous professional development (CPD) in early childhood education and care (ECEC) in Europe: Findings from a comparative review. European Journal of Education, 53(1), 23-33. https://doi.org/10.1111/ejed.12253.

Jensen, B., Jensen, P., \& Rasmussen, A.W. (2015). Does professional Development of preschool teachers improve child socio-emotional outcomes? Discussion Paper No. 8957.March 2015. IZA Germany. 
Kelchtermans, G. (2005). Teachers' emotions in educational reforms: Self-understanding, vulnerable commitment and micropolitical literacy. Teaching and Teacher Education, 21(8), 995-1006. https://doi. org/10.1016/j.tate.2005.06.009.

Kools, M., \& Stoll, L. (2016). What makes a school a learning organization? OECD Education Working Papers, No. 137, Paris: OECD Publishing.

Korthagen, F. (2017). Inconvenient truths about teacher learning: Towards professional development 3.0. Teachers and Teaching, 23(4), 387-405. https://doi.org/10.1080/13540602.2016.1211523.

Kovács I. V. (Ed) (2015). “OKOS KÖZNEVELÉS” Javaslat a Nemzeti Oktatási Innovációs Rendszer stratégiájának kiegészitésére. (Smart public education. Proposal for the Completion of the national innovation Strategy for education). "NOIR+Stratégia”. ELTE Pedagógiai és Pszichológiai Kar. Retrieved from: http://halaszg.elte.hu/download/A_NOIR_plusz_(2015.07.26).pdf.

Kovács I. J., Szivák J. \& Czachesz, E. (2020): A mesterpedagógus fokozat és a folyamatos szakmai fejlődés jellemzői óvodapedagógusok nézőpontjából. (The Master Teacher grade and the characteristics of continuous professional development from the perspective of kindergarten teachers). Iskolakultura, 30(9), 3-25. https://doi.org/10.14232/ISKKULT.2020.9.3.

Kwakman, K. (2003). Factors affecting teachers' participation in professional learning activities. Teaching and Teacher Education, 19, 149-170. https://doi.org/10.1016/s0742-051x(02)00101-4.

Kyndt, E., Gijbels, D., Grosemans, I., \& Donche, V. (2016). Teachers' everyday professional development mapping informal learning activities, antecedents, and learning outcomes. Review of Educational Research, 86(4), 1111-1150. https://doi.org/10.3102/0034654315627864.

Lénárd, S., Kovács, I., Tóth-Pjeczka, K., \& Urbán, K. (2020). A pedagógusok folyamatos szakmai fejlődését befolyásoló szervezeti tényezők. (The organizational factors influencing teachers' professional learning). Neveléstudomány, (1), 46-61. https://doi.org/10.21549/ntny.28.2020.1.3.

Lunczer, E. K. (2018). A pedagógus minősítési rendszer a jogszabályi változások tükrében (2013-2017). Opus et Educatio, 5(1), 9-26. https://doi.org/10.3311/ope.231.

Múñez, D., Bautista, A., Khiu, E., Keh, J., \& Bull, R. (2017). Preschool teachers' engagement in professional development: Frequency, perceived usefulness, and relationship with self-efficacy beliefs. Psychology, Society, \& Education, 9(2), 181-199. https://doi.org/10.25115/psye.v9i2.655.

OECD (2000). Knowledge management in the learning society. Paris.

OECD (2017). Starting strong 2017. Key OECD Indicators on early childhood education and care. Retrieved from: https://www.oecd.org/education/starting-strong-2017-9789264276116-en.htm.

Oktatási Hivatal: Útmutató a mesterpedagógus fokozatot megcélzó minősítési eljáráshoz. (Guidelines for the qualification procedure for the Master Teacher grade). (Harmadik, javított változat) Retrieved from: https://www.oktatas.hu/pub_bin/dload/unios_projektek/kiadvanyok/Mesterpedagogus_ harmadik.pdf.

Opfer, V. D. \& Pedder, D. G. (2011). Conceptualizing teacher professional learning. Review of Educational Research, 81, 376-407. https://doi.org/10.3102/0034654311413609.

Paniagua, A. \& Sánchez-Martí, A. (2018). Early career teachers: Pioneers triggering Innovation or compliant professionals? OECD Education Working Papers 190, OECD Publishing.

Qiu, H. (2018). Research on the burnout of high school teachers based on teacher professional development. Open Journal of Social Sciences, 6(12), 219-229. https://doi.org/10.4236/jss.2018.612019.

Rapos, N., Bükki, E., Gazdag, E., Nagy, K., \& Tókos, K. (2020): A pedagógusok folyamatos szakmai fejlődése és tanulása. Fogalmi változások. (The professional development and learning of teachers). Neveléstudomány, (1). 28-45. https://doi.org/10.21549/NTNY.28.2020.1.2. 
Schei, V., \& Nerbo, I. (2015): The Invisible learning ceiling: Informal learning among preschool teachers and assistants in a Norwegian kindergarten, Human Resource Development Quaterly, 26(3), 299-328. https://doi.org/10.1002/hrdq.21213.

Senge, P. (1998). Az 5. alapelv. A tanuló szervezet kialakitásának elmélete és gyakorlata. (The fifth discipline: The theory and practice of formulating a learning organization). Budapest: HVG Kiadó.

Sheridan, S. M., Edwards, C. P., Marvin, C. A., \& Knoche, L. L. (2009). Professional development in early childhood programs: Process issues and research needs. Early Education and Development, 20(3), 377401. https://doi.org/10.1080/10409280802582795.

Szarka, J. (2004). Az elkötelezett óvónő 2003-ban. (The committed kindergarten teacher in 2003). In Gyermek-Nevelés-Pedagógusképzés. Eötvös Lóránd Tudományegyetem Tanitó- és Óvóképző Föiskolai Kar Tudományos Közleményei XXVII. Budapest: Trezor Kiadó.

Szivák, J., \& Pesti C.s. (Eds.). (2020): A pedagógusprofesszió hazai megújításának esélyei a mesterpedagógus programok tükrében. (Opportunities for renewal of the teaching profession in Hungary in the light of the master teachers' programmes). L'Harmattan Kiadó.

Szivák, J., Rónay, Z., Saád, J., \& Fazekas, Á. (2019): A pedagógusok szakmai fejlődését, tanulását meghatározó rendszerszabályozási környezet. (Factors influencing teachers' professional development and learning at the Education System level) Educatio, 28(4), 829-837. https://doi.org/10.1556/2063.28. 2019.4.13.

Vujičić, L., \& Tambolaš, A. Č. (2017). Professional development of preschool teachers and changing the culture of the institution of early education. Early Child Development and Care, 187(10), 1583-1595. https://doi.org/10.1080/03004430.2017.1317763.

Wagner, B.D., \& French, L. (2010). Motivation, work satisfaction, and teacher change. Journal of Research in Childhood Education, 24, 152-171. https://doi.org/10.1080/02568541003635268.

Wenger, E., McDermott, R., \& Snyder, W. (2002). Cultivating communities of practice. Boston, Mass: Harvard Business School Press.

Open Access. This is an open-access article distributed under the terms of the Creative Commons Attribution 4.0 International License (https://creativecommons.org/licenses/by/4.0/), which permits unrestricted use, distribution, and reproduction in any medium, provided the original author and source are credited, a link to the CC License is provided, and changes - if any - are indicated. (SID_1) 